\title{
リモートセンシング 概論
}

東京大学生産技術研究所村井俊治

リモートセンシング (Remote Sensing) の技術は，すでに 1960 年代初期から研究が始められ てきたが, 最近のエレクトロニクス, 人工衛星, コンピューター, 分光工学などの発達により, 従 来の航空写真の分野む包括されたりモートセンシングの分野が開拓された. ここでは述べなければ ならない多くのものから，特にリモートセンシング情報処理システムについて概説する.

\section{1. リモートセンシングの概念}

まずはじめに，リモートセンシングとはなにかを簡単 に述べてみよう. リモートセンシングは, 日本語で遠隔 探査と訳されるととがあるが，内容は以下のとおりであ る.

リモートセンシングとは，直接手に触れないで，対象 物や現象に関する電磁放射の情報を収集し，われわれの 環境を調査する技術である.

収集される情報は，対象物から反射または放射される 電磁スペクトルに関する情報である.

電磁スペクトルに関する情報を収集する装置をセンサ 一といい, カメラやマルチスペクトルスキャナーなどが ある. センサーが搭載されるところはプラットフォーム とよばれ，航空機や人工衛星などがこれにあたる.

リモートセンシングの定義を言いなおすと, “リモー トセンシングとは，航空機や人工衛星などのプラットフ オームに搭載されたセンサーを用いて, 地表の対象物か ら反射または放射される電磁スペクトルを測定し，それ らのデータを用いて, 対象物や現象に関する情報を得る 技術である”となる.

リモートセンシングにおいて, 電磁スペクトルの情報 を収集するととにより，対象物や現象を判読するととが できるのは，つぎに述べるような物体のスペクトル特性 による、すなわち，“すべての物体は，種類および環境 条件が異なれば，乙とごとく異なる電磁波の反射または 放射のスペクトル特性を有する”。

\section{2. リモートセンスされるデータ}

航空機や人工衛星などのプラットフォームから地上の 物体のスペクトル特性を測定する場合, リモートセンス

"General Description on Remote Sensing” by Shunji Murai (Institute of Industrial Science, University of Tokyo, Tokyo)
されるデータは，つぎの要因に依存する.

（1）物体の反射または放射のスペクトル特性

（2）光源（太陽）のスペクトル特性

（3）光源の入射角と物体およびセンサーの位置関係

（4）大気の反射, 放射, 透過, 吸収, 散乱の特性

（5）センサーの特性

図 1 は, 対象物, 光源 (太陽), 大気, センサーの間の 電磁波の経路を示している，乙の図加らあわかるように リモートセンスされたデータには，対象物からの電磁ス ペクトルのほかに，大気からのノイズが含まれる，また センサーの性能に起因する各種の誤差やひずみがある.

したがって，センサーによって収集されるデータは， 地表の物体のスペクトル特性そのものでなく， ラジオメ トリックおよび幾何学的な䛊差を有する画像データであ る.

\section{3.リモートセンシング情報処理システム}

リモートセンシング情報処理システムは，つぎの機能 をあつととが必要である.

(1) データ収集

人工衛星, 航空機扝よび地上に掞いて電磁スぺ クトルの測定を行う. 地図や資料などからの補助

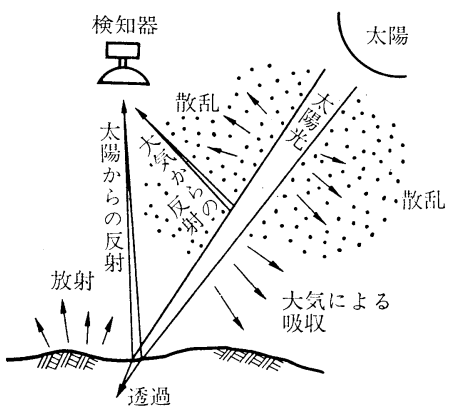

図 1 リモートセンシングの概念 


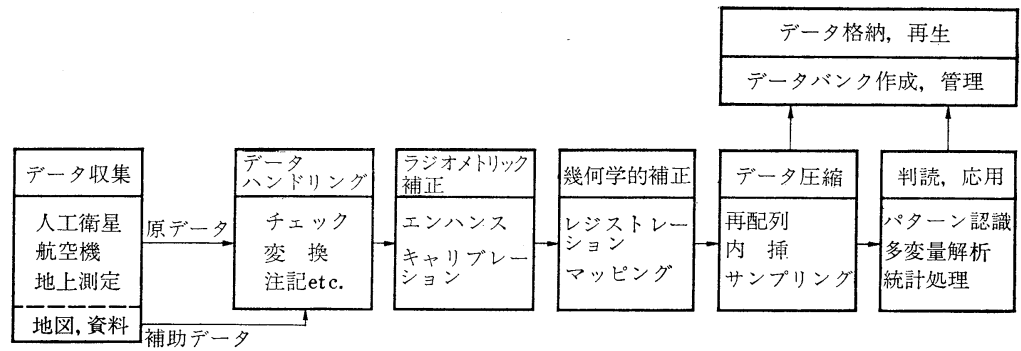

図 2 リモートセンシング情報処理システム

データの収集む含まれる。

(2) データハンドリング

収集された原データを後続作業に便利なように 変換, 注記, 数值化, ディスプレイなどを行う.

(3) ラジオメトリック補正

画像のエンハンスや, 太陽入射角, 視野角, 雲 などによる影響を補正する。

（4）幾何学的補正

レジストレーションやマッピングの幾何学的補 正を行う.

(5) データ圧縮

データの格納と再生に便利なように，再配列， 内挿，サンプリング等を行う.

(6) 判読求よび応用 パターン認識, 多変量解析, 統計処理などによ り対象物を識別し，現象を解析する.

（7）データ格納および再生

リモートセンシング画像データバンクを作成す る.

以上に述べた機能の流れを図示すると，図2のように なる. 以下に上記の機能について概観することにしよ う.

\section{4. デー夕収集}

リモートセンシング画像のデータを取り扱ううえでの むずかしさは，つぎに述べる原因による.

（1）データがきわめて多量であり, 多次元である.

（2）数多くのセンサーの種類があり，それぞれデー タフォーマット, 解像力, 座標系, 精度等が異な る.

（3）環境条件，地域，時間による変動が大きいにも かかわらず，対象物や現象の変化の検知をしなけ ればならない。

(4) ノイズが含まれている.

(5) 数多くの前処理や補正が必要である.

（6）異なるチャンネル間の画像の重㸚合わせのほか
に, 地上の地理的位置との対応が必要である.

（7）画像デー夕之，地上調查や補助デー夕との対応 をつけなければならない。

現在, 開発されているセンサーにはつぎのものがある.

(a) 航測カメラ (MC)

(b) マルチバンドカメラ (MBC)

(c) マルチスペクトルスキャナー (MSS)

(d) サイドルッキングレーダー (SLR)

(e) スペクトロメーター (SPM)

（f） マイクロウェーブラジオメーター (MWR)

(g) レーザーレーダー (Lidar)

(h) スキャタロメーター (SCM)

表 1 は上記のセンサーと波長バンド，チャンネル数ま たはバンド数, 視野角, データ様式を示したものである。

表 1 センサーとデータ様式

\begin{tabular}{|c|c|c|c|c|c|}
\hline センサー & $\begin{array}{c}\text { 波長バンド } \\
(\mu)\end{array}$ & $\begin{array}{l}\text { F方数 } \\
\text { 齐 }\end{array}$ & $\begin{array}{l}\text { 視野角 } \\
\text { (度) }\end{array}$ & 解像力 & データ様式 \\
\hline $\mathrm{MC}$ & $0.4 \sim 0.88$ & 1 & $90 \sim 120$ & $0.1 \mathrm{mrad}$. & フィルム \\
\hline MBC & $0.4 \sim 0.88$ & 4 & 30 & 0.15 mrad. & フィルム \\
\hline MSS & $0.38 \sim 14.0$ & 11 & 90 & 2 mrad. & $\begin{array}{l}\text { FM テープ } \\
\text { HDDT }\end{array}$ \\
\hline SLR & $\begin{array}{c}3 \times 10^{4} \\
(10 \mathrm{GHz})\end{array}$ & 1 & 50 & $15 \mathrm{~m}$ & フィルム \\
\hline SPM & $\begin{array}{l}0.1 \sim 1.0 \\
1.0 \sim 100\end{array}$ & 1 & 20 & $1 \mathrm{mrad}$. & FM テープ \\
\hline MWR & $\begin{array}{c}2 \times 10^{4} \\
(14 \mathrm{GHz})\end{array}$ & 1 & 48 & 26 mrad. & $\mathrm{FM}$ テープ \\
\hline Lidar & 0.63 & 1 & 1 mrad. & $1 \mathrm{~m}$ & $\mathrm{FM}$ テープ \\
\hline $\mathrm{SCM}$ & $13.3 \mathrm{GHz}$ & 1 & 120 & $25 \mathrm{~m}$ & $\mathrm{FM}$ テープ \\
\hline
\end{tabular}

\section{5. データハンドリング}

データハンドリングでは，主に原データを，写真処 理, 変換, 数值化などにより, 陽画や CCT などに変換

表 2 データハンドリング

\begin{tabular}{|c|c|c|}
\hline 原 データ & 変 換 方 法 & 変換データ \\
\hline フィルム & 琴像処理 & $\begin{array}{l}\text { トランスパレンシィ, } \\
\text { プリント CCT }\end{array}$ \\
\hline アナログ磁気テープ & $\left\{\begin{array}{lll}A A & \text { 弯 } & \text { 換 } \\
\text { AD } & \text { 換 }\end{array}\right.$ & $\left\{\begin{array}{l}\text { 写真，図 } \\
\text { CCT }\end{array}\right.$ \\
\hline $\begin{array}{l}\text { ハイデンシティーディジ } \\
\text { タルテープ (HDDT) }\end{array}$ & $\mathrm{DD}$ 変 換 & CCT, ディスプレイ \\
\hline
\end{tabular}




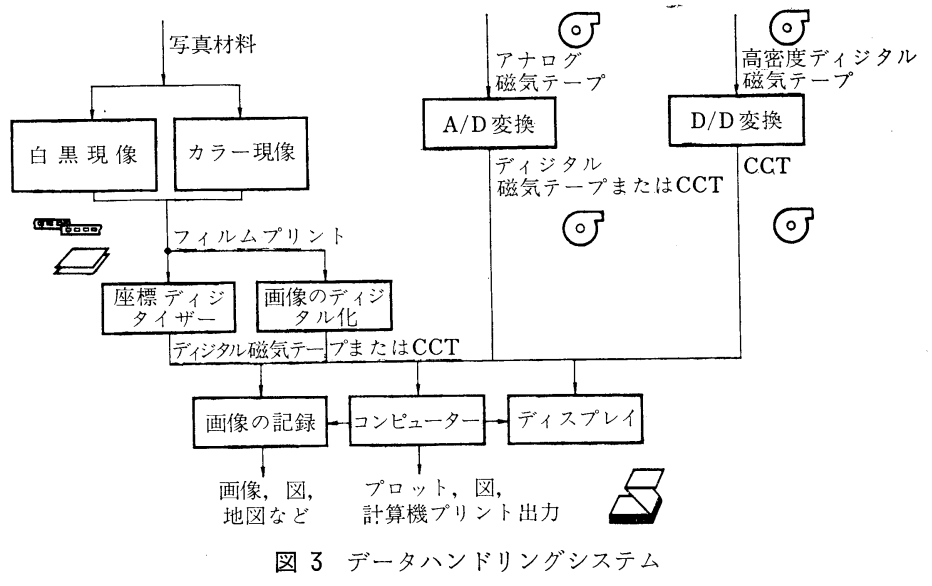

する. 表 2 はデータハンドリングによる変換を示して

おり，図3はデータハンドリングのシステムを示して いる.

ディジタル処理する場合には，フィルムの場合ディジ タイザー, アナログテープの場合 $\mathrm{AD}$ 変換器, ハイデ ンシティーディジタルテープの場合 DD 変換器 (ディジ タルのデータを他のディジタルデータに変換する装置) により CCT (コンピューター用磁気テープ) に変換し なければならない。

\section{6. ラジオメトリック補正}

画像データの前処理としてラジオメトリック補正が必 要である.ラジオメトリック補正にはつぎのむのがある.

(1) エンハンスメント

濃度分割，等濃度図作成，コントラスト強調， 加減算，スムージング，フィルタリング，微分な どを行う。

（2）画像データの補正

画面の位置に関係なく，画面全体にわたって補 正の必要なものと, 点の位置によって, 一点一点 画像デー夕を補正しなければならないあのとがあ る. 後者の毛のには, シェーディング, 太陽光入 射角, 視野角など, 定性的かつ定量的に補正の可 能なるのと, 輝度変調, 雲のかげ, 地形起伏など, 補正の团難なあのとがある.エンハンスメントに ついては, 徒来加ら画像工学の分野で画像処理の 技法として取り扱われているので，乙こでは省略 する.

（3） キャリブレーション

異なるセンサー，日時，画面のデータを参照体 や基準に合わせて補正する必要がある.

\section{7. 幾何学的補正}

画像データの幾何学的補正のつぎに示す場合に必要と なる。

（1）地理的な位置を正確に求めたいとき.

（2）異なるスペクトルバンドの画像を重ね合わせた いとき.

（3）異なる日時またはセンサーでとられた同じ場所 の画像を重放合わせたいとき.

幾何学的な誤差やひずみはつぎの原因によるものに分 類できる.

（a）センサーの幾何学的特性に起因した誤差

（b）プラットフォームの姿勢に起因した䛊差

（c）地表の起伏に起因した誤差

現在，リモートセンシングにたずさわっている人達が 主に直面する幾何学的補正の問題は，大きくわけるとつ ぎの3つの場合である.

(1) レンズカメラによる写真画像

得られる画像は中心投影像である. 写真の幾何 学は写真測量の分野で扱われている. 一般に 1 枚 の写真加ら撮影された対象物の3 次元的位置を求 めることができないので，実体ステレオ写真を用 いて地理的位置を求める. マルチバンドカメラに よる写真の重袷わせはアナログ光学的には，人 間の視覚にたよって行われる. ディジタルの場合 には，いわゆる指標 (fiducial mark) がないので, ディジタイズするときに座標系の軸を合わすか, あとでソフトで重稀わせをするかしなければな らない，㛜密な正確さは期待できない，航測用力 メラを 4 台使用したマルチバンド写真をとるとと が可能であれば，指標を用いたディジタル化が可 能となる. 日時の異なる写真どうしの重ね合わせ は，中心投影点，すなわちカメラの位置が異なれ。 
ば中心投影像の特徴からして不可能である.ただ し，実体視は可能である場合がある。

(2) 航空機搭載マルチスペクトルスキャナーの画像 将来乙の画像が多くとられると思わ机るが，幾 何学的問題の面からは一番困難である. すなわ ち，異なるチャンネル間の画素の重悋合わせは， 写真に比較して完全であるが，1つ1つの画素が 地上のどての位置に対応しているかをディジタル に処理することに多くの問題点があるからであ る.まず，航空機は 3 軸の傾きをもち，高度およ びコースも変動する．このため，スキャンライン は平行かつ等長であるとは限らない，航空機の姿 勢に関する情報はジャイロからのものしか期待で きないが、ジャイロの情報はきわめて精度が低い. 仮りに航空機が安定して航行しても，地形の起伏 のために画像のディストレーションが局地的に生 ずる. 写真の場合にくらべてむずかしいのは，写 真では 1 枚の画面内で同じ幾何学がなりたつのに 対し，スキャナー画像では 1 本 1 本のスキャンラ インごとに異なる幾何学的条件を考慮しなければ ならないととによる，要約するなら，地形が平坦 なところであれば，高次の多項式を用いてスキャ ン画像の地理的補正は可能であるが，一般には地 図化のための高い精度は望めない。

（3）人工衛星搭載マルチスペクトルスキャナー の画像

この場合，航空機搭載のものとくらべて異なる のは，地表が平坦あるいは回転棈円体と見てさし つかえないことである．また人工衛星の飛行状態 が航空機にくらべはるかに安定しており，西るゃ 加連続した姿勢変化しかしない。しかし，人工 衛星は 3 軸の傾きを持ち，高度変化すする．また 1 本のスキャンの間に衛星は動くし, 地球も動く. またスキャンミラーの速度も一定ではないので， スキャンラインの対地速度は正弦曲線に似た変化 をする．とのような幾何学的ひずみをすべて合成 すると，3次の高次多項式でほぼ補正することが 可能となる. 画像の中に良好な基準点があれば, 著者の経験からすれば，地球資源衛星 (ERTS)の 画像で $100 \mathrm{~m}$ 以内の地理的補正が可能である.

ディジタル処理のなかで幾何学的補正はきわめて重要 な部門を占めているので，あう少しくわしく述へててよ う.

いま画像座標を $(u, v)$ とし，それに対応する地上の 点の座標を地上の測地座標を $(X, Y, Z)$ 上すると, つぎ の関数関係がなりたつ.

$$
\left\{\begin{array}{l}
u=f(X, Y, Z) \\
v=g(X, Y, Z)
\end{array}\right.
$$

写真の場合, 焦点距離 $f$ と, 基準点の座標を与えて, カメラ位置 $\left(X_{0}, Y_{0}, Z_{0}\right)$ 拈よび 3 軸の傾き $(\kappa, \varphi, \omega)$ を 解くことにより, 上記の関数関係が求まる.

ERTS のマルチスペクトルスキャナー画像の場合, 地形の起伏を考慮しなくてよいから Z は考えなくてよ い. 乙の場合, 3 次の高次多項式をあてはめ, 画面内に 約 20 点ないし 30 点の基準点を設定して, 多項式の係 数を求めればよい.

\section{8. デー夕圧縮}

データ压縮は，つぎの目的で行われる。

（1）無用のデータを除去する.

（2）特徴やパラメーターの形でデータを保存する.

（3）精度をおとしても，計算処理時間を短縮する。

（4）記憶容量を節約する.

データ圧縮は，データをなるべく少なくして，得る情 報を多くしようとする技術ともいえる。データ圧縮の方 法は，つぎのようなあのがある。

(a) 等間隔にデータ老除去する.

(b) 等時間でとにデータを除去する.

(c) ランダムにデータ除去する.

（d）ある関数のもとにデー夕除去または保存を行 う.

（e）特徴のあるデータのみ保存する.

画像データの圧縮の場合, 除去したデー夕を保存され たデータから内插して画像化すると，だいたい $1: 6 く ゙$ らいのデータ圧縮をしても人間の視覚ではほとんど差が わからないといわ机ている。

\section{9. 判 読}

リモートセンシングのなかでも最む重要な部門であ る.

いま，一般化するために，マルチスペクトルの画像の 信号が， $x_{1}, x_{2}, \cdots \cdots, x_{n}$ とし， 乙机が地上で， ある分 類 $y$ であるとすると, リモートセンシングの判読は，つ ぎの関数関係を求めるととになる.

$$
y=f\left(x_{1}, x_{2}, \cdots \cdots, x_{n}\right)
$$

この関数には，大気の影響や画質などによる影響因子 が含まれている，また，信号のばらつきがあって，ある 種の分布を構成する.

ここで,yは連続量でなく分類量であり, 記号でも数 字であよい值であり， $x_{i}$ は一般には連続量と考えられ るが，濃度分割や区分の仕方によっては分類值と考えら れる場合あある.したがって一般には，多変量解析の手 

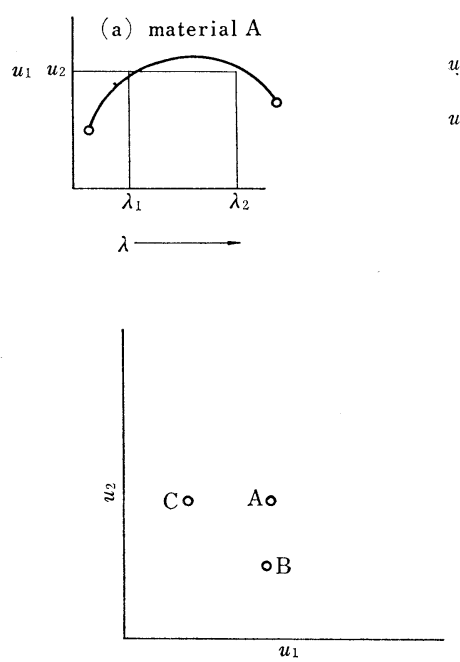

(b)

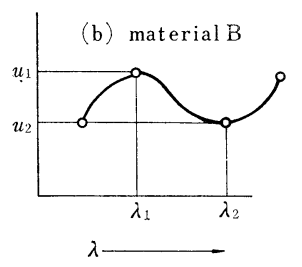

(a)

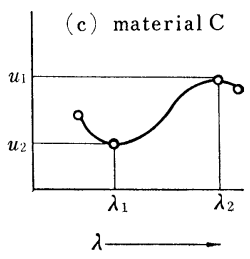

図 4 グランドトルスデータを用いた自動判読の原理

法が有効に利用できる.

自動判読の方法は大きくわけると，つぎの 5 つになる.

(1) グランドトルスを用いる方法 (supervised techniques)

グランドトルス（地上で測定されたスペクトル 特性のデータ) により, あらかじめ有限籄所およ び有限個の既知の物体の $y^{*}$ と $\left(x_{1}^{*}, x_{2} *, \cdots \cdots\right.$, $\left.x_{n}{ }^{*}\right)$ の測定をして招き, 画像座標 $\left(x_{1}, x_{2}, \cdots \cdots\right.$, $\left.x_{n}\right)$ の中で識別領域を確立しておき, 未知の $\left(x_{1}\right.$, $\left.x_{2}, \cdots \cdots, x_{n}\right)$ に対する $y$ を判読する.

この方法の長所は, 地上調査の結果を用いるの で，調査法さえ完全なら精度が良いことである。

欠点は, サンプリングの選択を適正に行うことが 大変なのと, 労力のかかるととである (図 4 参照).

（2）相対的な分類を行う方法 (unsupervised techniques)

グランドトルスデータを用いないで, $\left(x_{1}, x_{2}, \cdots\right.$ $\left.\cdots, x_{n}\right)$ の画像空間の中で同一グループを形成して いると思われる有限個のグループに分け，それら のグループが何を意味しているかを地上調查によ り求める.この方法の長所は，グランドトルスの 収集が不要であることと，画像に現われた新しい グループを見出せることである. 欠点は，グルー プのもつ意味が，従来用いられてきた分類や階級 の尺度と合わないとこである.

（3）グランドトルスを累積利用する方法 (adaptive techniques)

*印は既知の物体を指す
最初は与えられたグランドトルス $y^{*},\left(x_{1}{ }^{*}\right.$, $\left.x_{2}{ }^{*}, \cdots \cdots, x_{n}{ }^{*}\right)$ の組から (1) の方法により判読 を始めるが，新しく判読された $\left(x_{1}, x_{2}, \cdots \cdots, x_{n}\right)$ をつぎつぎとグランドトルスのデータの中に加え てゅく方法である. ての方法の長所は, グランド トルスの調査の欠点を補充できることである. 欠 点は，1点 1 点ごとに識別領域を更新しなければ ならないことである。

（3）構成比を求める方法 (classification of unresolved objects)

ERTS 画像の画素などのように, 1 つの画像デ 一夕 $\left(x_{1}, x_{2}, \cdots \cdots, x_{n}\right)$ が 1 つの物体ではなく, いくつかの物体の合成亡考えられる場合, 画像デ 一タから常に1つの物体を判別しようとすると精 度が悪くなる. このため,いくつかの物体 $y_{1}, y_{2}$, $\cdots \cdots, y_{m}$ を説明変量亡して扱い， ある画像データ $\left(x_{1}, x_{2}, \cdots \cdots, x_{n}\right)$ がごのような物体の構成比で構: 成されているかを求める。乙の方法は，境界線付 近や解像力の悪いデータあるいはデータ圧縮など によるデータなど平均化されたデータの取り扱い に有効である. 欠点は, 訃算に時間がかかるとと。 である。

（5）分割地区ごとに判読する方法（perfield classification)

上記の 4 方法は，いずれも 1 点 1 点の画素ごと の判読であったが，乙の方法は，まず最初に境界 をなんらかの方法で求めて多数の小分割地区に分 け，分割地区でとに判読する方法である．この方 法の長所は, 地区が分割されてからは, 判読が迅 
速で精度が高いことである. 欠点は小地区に分割 するととが大変であることである。

上記の方法に特有あるいは共通の手法を数学的な見地 から拾い出すと，つぎの手法が必要となる.

(1) 統計解析

画像データの平均，分散および相関などをしら べる.

(2) 主成分分析

チャンネルが 12 ぐらい多い場合, 12 次元全部 を用いなくても，主成分のチャンネルを 4 つか 5 つ減少させたいときに用いる。

（3）重回帰分析および正準相関分析

グランドトルスデータの組〔( $\left.y_{1}, y_{2}, \cdots \cdots, y_{m}\right)$; $\left.\left(x_{1 i}, x_{2 i}, \cdots \cdots, x_{m i}, i=1, n\right)\right]$ 亿対して合成変数の 相関を最大にするようなモデルを求める，ただし この場合 $x, y$ とあに連続量とする.

(4) 判別分析

2 つ以上の $y_{i}$ を判別する手法で，一般には， 誤判別の確率を最小にするような判別を行う．グ ランドトルスデータが完備している場合に有効で ある。

(5) クラスタ分析

画像データのみを用いて，同一集群之思わ机る 有限個の領域に分割する。クラスタ分析は，グル ープ間の距離を最大にするようにグループ構成が 考えられるが，種々の距離に関する概念があり， 煩雑である.

（6）分散分析または数量化理論

$y$ を説明変量にして, $\left(x_{1}, x_{2}, \cdots \cdots, x_{n}\right)$ の画像 データを合成する $y_{1}, y_{2}, \cdots \cdots, y_{m}$ の構成比を求め るような場合に用いられる。

\section{0. データ格納および再生}

データ格納および再生は, 多量のリモートセンシング デー夕を有効に利用するために，きわめて重要な役割を
果たす、データバンクを作成する場合には，つぎの $3 つ$ のファイルが必要となる.

(1) 経歴ファイル

画像の原データ掞よび補助データなどを保存し ておく、グランドトルスデータや他の資料のデー 夕屯保存する。

(2) 作業ファイル

最終成果を得るために関係したすべてのデータ を保存しておく

(3) 利用ファイル

システムおよび応用ソフトゥエアに関する情 報，物体のスペクトル特性，ファイルカタログな どのデータを提供する.

以上のととから，リモートセンシング画像のディジタ ル処理システムの機器構成を考えると図 5 のようにな る、ただし，ての中にはデータハンドリングの関係は含 まれていない。

\section{1.リモートセンシングの応用}

いままで，リモートセンシングとは何か，またどのよ うな方法であるかを概観してきたが，つぎに，リモート センシングの技術がどのような応用分野と可能性をすつ かを述べてみよう.

(1) 応用分野

a. 農業: 作物調查, 収獲量予測, 病虫害調査など

b. 森林: 森林調査, 病虫害調査, 山火事発見など

c. 土地利用：土地利用図の作成

d. 都市 : 都市環境調査, スプロール調査など

e . 水資源：河川調査，洪水被害調査，積雪調查な ぞ

$\mathrm{f}$. 海洋資源 : 水温調查, 海流調查, 海岸調查など

g. 公害: 大気污染, 水污染, 植物活力調査など

$\mathrm{h}$. 気象: 雲の調查, 天気予報, 台風調査など

i . 地質 : 鉱脈, 油脈, 断層, 構造線の発見など

（2）リモートセンシングに要求される条件

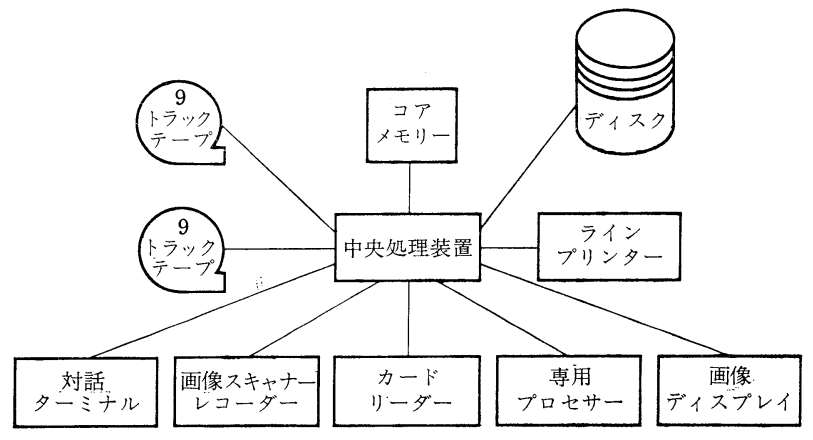

図 5 ディジタル処理システム 
応用分野によってつぎの要求条件が異なる.

a. 周期：リモートセンシング画像は，ある年月日

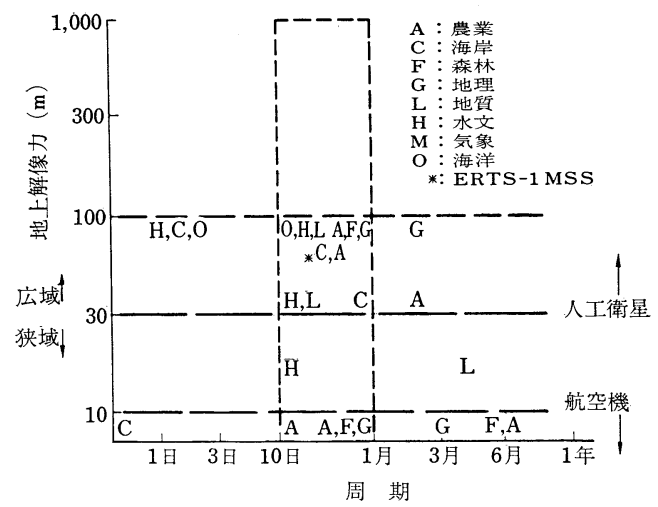

図 6 地上解像力之周期

波 長 ( $\mathrm{nm}$ ) (カッコ内の数字は解像力)

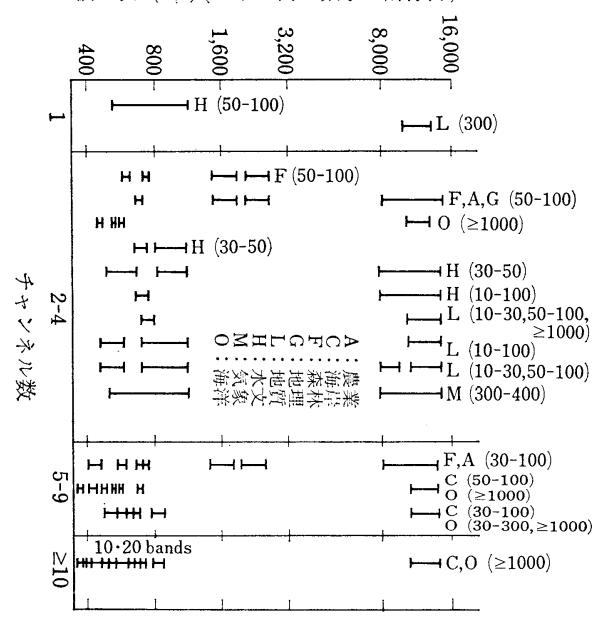

図 7 波長帯域とチャンネル数
時における情報を提供してくれるが，分野によ

っては，時系的な情報が必要となる．

b. 地上解像力：地上のどのくらい詳細な情報が必 要であるかは応用分野によって異なる。

c . 波長およびチャンネル数：応用分野によって必 要な波長帯域掞よびチャンネル数が異なる.

図 6 は, 分野によって要求される地上解像力之周期の 関係を表わしており, 図 7 は, 分野に必要な波長帯域と チャンネル数を示している.

(3) 応用例

数多くの応用例があるが, 紙数の関係で公害調査関係 のあのを3つあげよう.

写真 1 は, サーマルスキャナー (熱映像装置)によっ てとられた画像である，白いところほど温度が高く，黒 いところほど低い，河川沿いにある発電所から出された 温排水が湖に拡散する状沿がよくわかる，乙のような調 査は, 数時間ごとに撮影して, 水量, 風向, 潮流などの 関係を解析する必要がある，とのような熱映像から現在

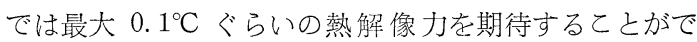
きる.

写真 2 は, マルチスペクトルスキャナーを用いて河川

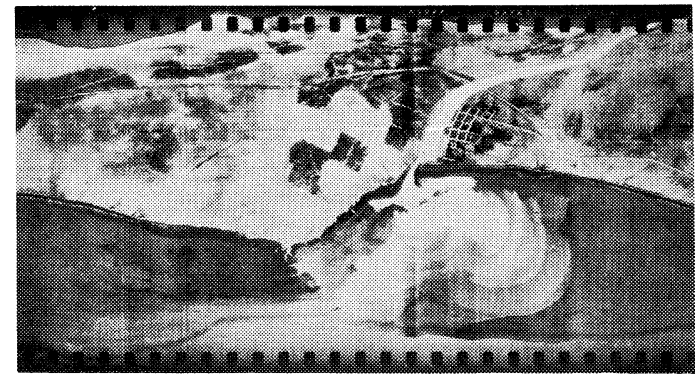

写真 1 サーマルスキャナーによる温排水の熱胦像
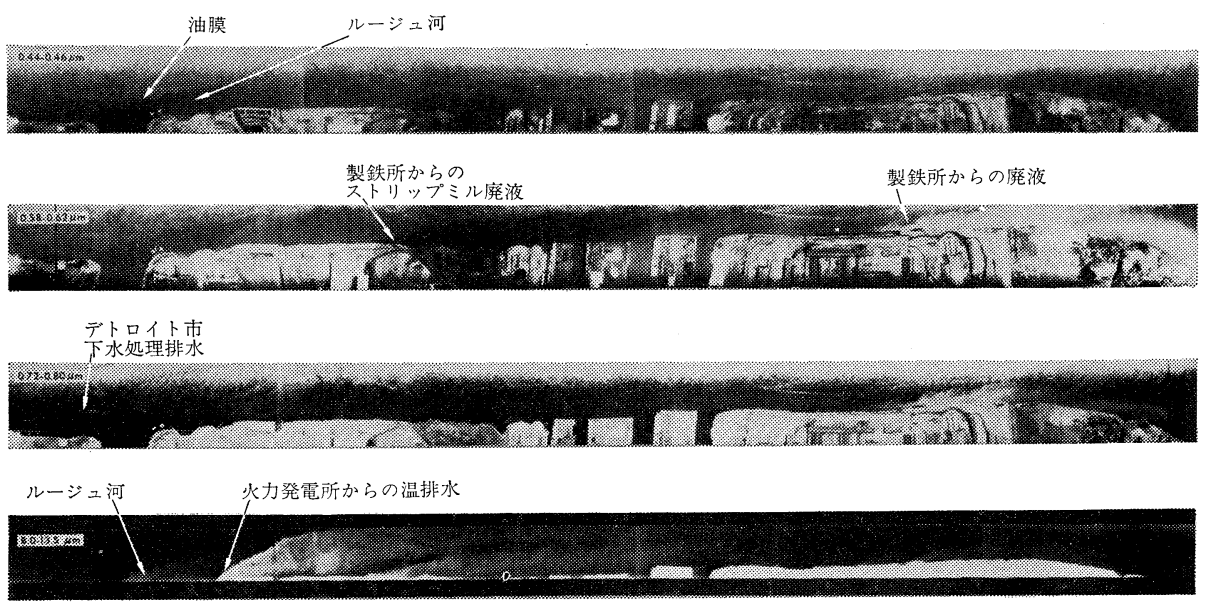

写真 2 マルチスペクトルスキャナーによるデトロイト河の工業排水の調査 


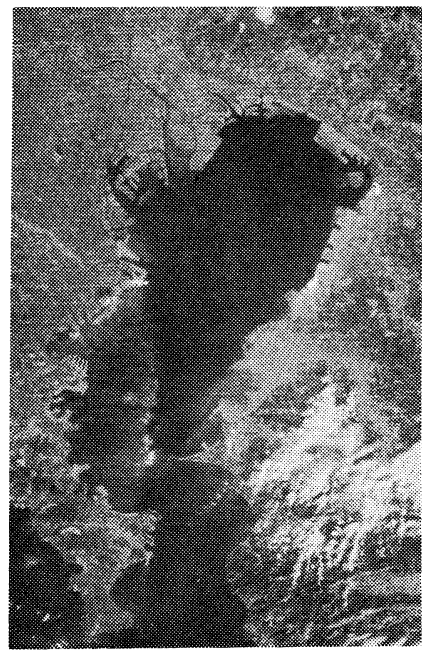

写真 3 東京湾上に流れ出た京浜工 場地帯のスモッグ集団 (ERTS 衛星 1973.1.19)

沿いにある工場地帯をリモートセンスした例である.波
長によって工業排水のスペクトル特性が異なることよが くわかる。

写真了では，ERTS-1 によってとらえられた東京湾 岸の工場群の出す煙やスモッグの動きがよくわかる．京 浜工業地帯加らの煙と, 京葉工業地帯からの煙が富津岬 付近で合流している．よく見ると京浜工業地带の煙突か らの煙の玉とその影が見える。（昭和50年1月28日受付)

\section{〔参 考 文 献〕}

1) European Research Organization: Data Preprocessing Systems for Earth Resources Surveys, Sep. (1973)

2）日本リモートセンシング研究会 (JARS)：リモートセン シングの原理と応用 (昭 49.10)

3) Proceedings of ASP Symposium: Management and Utilization of Remote Sensing, Oct. (1973)

4) Estes \& Senger: Remote Sensing, Hamilton Publishing Co. (1974)

5）村井俊治：環境のリモートセンシング, 資源, No. 186, 資源協会発行（昭 48.11）

6) 村井俊治：リモートセンシングデータの解析, 電学誌, 94, 11 (1974)

\section{テレビジョン 4 月特集号「画像伝送」予定目次}

【随想】画像技術への期待

1. 画像伝送の現状之将末

2. テレビジョン放送における画像伝送

2-1 テレビジョン放送網の現状

$2-2$ 運行設借

2-3 送信設借

2-4 テレビジョン中継回線

2-5 衛星中継

2-6 受像機

3. 受信環境上の諸間題

3-1 建造物による受信障害

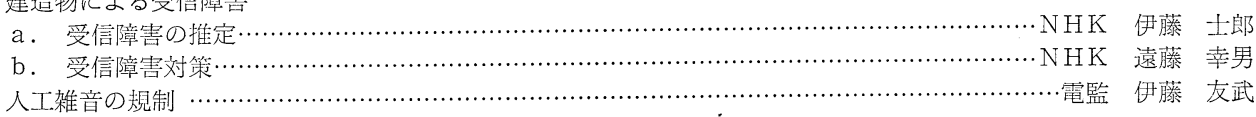

.電電公社 緒方 研二 東大 宮川 洋

電監 三浦 信

- NHK 石村 金三 東京放送 米沢隆 電電公社 西野 孝平 ・橋本了 国際電電 佐藤 秀夫 松下電器 佐々木玲一

4. 将来のテレビ放送における画像伝送
4-1 多重放送
NHK 沼口 安隆
4-2 S H F 放送
NHK 王丸 謙治
4-3 街星放送
NHK 泉 武博
5. CATV.....
日電 三森 理一
6. テレビ電話
6-1 テレビ電話網
6-2 ディジタル伝送
6-3 带域圧縮
6-4 画像品質
武藏野通研 大森喬 武蔵野通研 大川原忠義 ……日電 石黒 辰雄

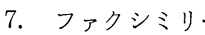 武藏野通研 小林 幸雄
8. 医療用画像伝送 東大生研 安田 靖彦
9.教育用西像機器 日立電子 宮本 庸一 東芝商事 三浦 勝夫 